\title{
First report of Pseudoidium sp. causing powdery mildew on Tecoma capensis in India
}

\section{Wagh SH and Kanade MB}

P. G. Research Center, Department of Botany, Tuljaram Chaturchand College of Arts, Science and Commerce, Baramati, Dist. Pune - 413 102, Maharashtra, India

Wagh SH, Kanade MB 2021 - First report of Pseudoidium sp. causing powdery mildew on Tecoma capensis in India. Plant Pathology \& Quarantine 11(1), 83-85, Doi 10.5943/ppq/11/1/9

\begin{abstract}
In December, 2020 leaves of Tecoma capensis with typical symptoms of powdery mildew fungus was collected from the Baramati area of Pune district (M.S.), India. Based on its morphological characters, the pathogen was identified as Pseudoidium sp. (Erysiphe sp.). This work is emphasizing on first record of powdery mildew fungus Pseudoidium sp. on Tecoma capensis (Thunb.) Lindl. from India.
\end{abstract}

Keywords - Erysiphe - Powdery mildew

\section{Introduction}

Tecoma capensis (Thunb.) Lindl. commonly known as cape-honeysuckle, evergreen fast growing ornamental shrub belonging to the family Bignoniaceae. It is native of Southern Africa and widely cultivated in warm temperate and tropical areas (Jothi et al. 2011). Leaves odd-pinnately compound, opposite, leaflets oval with blunt theet. Flowers orange to orange-red, available throughout the year (Singh et al. 2001). In traditional medicine T. capensis used to relieve pain and sleeplessness (Saini et al. 2012) and the anticancer activity were reported from crude methanol extract of $T$. capensis by Hamed et al. (2016).

The $T$. capensis are frequently found to be infected with powdery mildew fungus from study area. During the study morphological characters of host and microscopy of powdery mildew fungus were studied. It is revealed from the study that pathogen is Pseudoidium sp. and which is first time reported from Maharashtra state as well as India.

\section{Materials \& Methods}

The study area was Baramati, Dist. Pune, Maharashtra, India $\left(18^{\circ} 16^{\prime} 04^{\prime} \mathrm{N}, 7^{\circ} 58^{\prime} 03^{\prime} \mathrm{E}\right.$, Altitude $555.19 \mathrm{~m}$ ). The infected leaves of T. capensis were collected during 2020-2021. Infection was more severe in months of January to March and totally absent during the rainy season. The infected material properly pressed, dried and the voucher specimen was deposited in the Ajrekar Mycological Herbarium at Agharkar Research Institute, Pune (M.S.), India (Accession No.AMH10362). The fungal material was taken by leaf scraping, stained with cotton blue, mounted in lactophenol and microscopically examined under the Laben Research Microscope BM- 3000T (Binocular version). 
Pathogenicity test was conducted in laboratory conditions at $24-28^{\circ} \mathrm{C}$. In which potted $T$. capensis leaves were inoculated by conidial suspension of Pseudoidium. non-inoculated plants considered as control. After 7 to 9 days of inoculation same symptoms were observed on inoculated hosts which were recorded in the field conditions and Pseudoidium was resolated from the same.

\section{Results \& Discussion}

While the microscopic examination of fungus only anamorphic stage was found. The anamorph has morphologically characterized as: mycelium amphigenous, thin, forming patches; hyphae septate, hyaline, profusely branched; hyphal appressoria distinctly or slightly nipple shaped (Fig. 1f). Conidiophores erect, arises from the upper surface of mycelium, foot cells short, straight, cylindrical up to $22.44-26.18 \times 07.48 \mu \mathrm{m}$ and average $23.18 \times 07.48 \mu \mathrm{m}$ followed by $1-2$ shorter cells (Fig. 1c). Conidia ellipsoid-ovoid to doliiform-cylindrical about 26.18-41.14 x 14.96-18.07 $\mu \mathrm{m}$ and average $33.66 \times 15.33 \mu \mathrm{m}$ (Fig. 1d), fibrosin bodies absent and conidia formed singly. Germ tubes terminal to subterminal, more or less straight and about 52.36 to $104.72 \mu \mathrm{m}$ length (Fig. 1e).
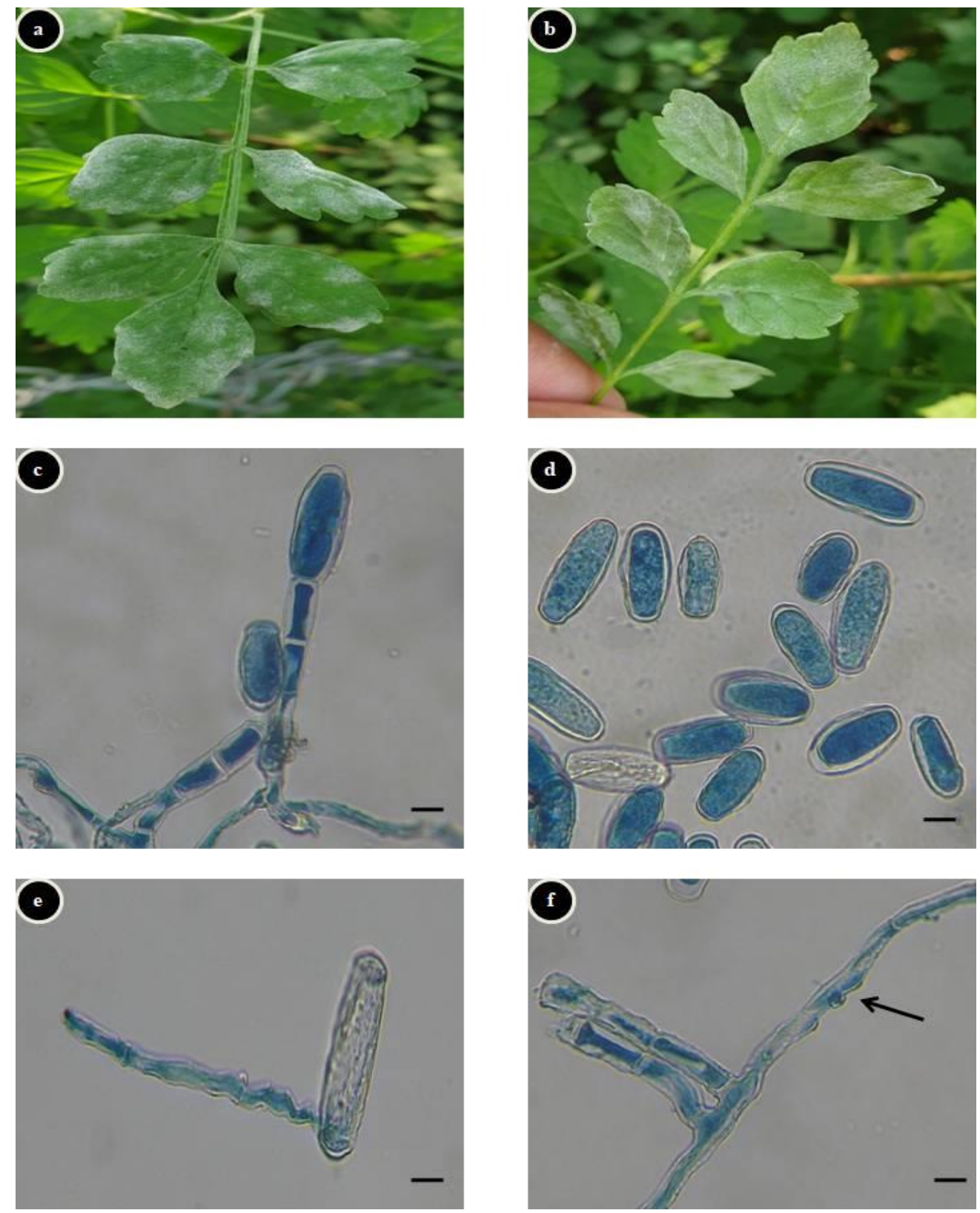

Fig. 1 - a Infected upper surface of leaf. b infected lower surface of leaf. c conidiophore (40x). $\mathrm{d}$ conidia (40x). e germinated conidium. f arrow indicates hyphal appressorium. Scale bar $=20 \mu \mathrm{m}$. 
Considering the disease symptoms and microscopic characters of powdery mildew fungus on T. capensis, pathogen has confirmed as species of Pseudoidium (Braun \& Cook 2012). According to the new ICN rules, Pseudoidium Hammet. is now a heterotypic synonym of Erysiphe DC. The teleomorph was found absent throughout the study.

As the literature available of powdery mildew, it is noticed that, Erysiphe peruviana first time reported from North America on T. capensis (Glawe et al. 2010) and Oidium hiratae (Fibroidium hiratae) first time reported from India on T. capensis (Paul \& Thakur 2006, Hosagoudar \& Agarwal 2009). As well as in the present study we also recorded Pseudoidium sp. on the same host plant. So, we concluded that, this is the first report of powdery mildew caused by Erysiphe sp. (Pseudoidium sp.) on Tecoma capensis from India.

\section{Acknowledgements}

First author Wagh SH is grateful to the Chhatrapati Shahu Maharaj Research, Training and Human Development Institute (SARTHI), Pune for providing Ph.D. Fellowship.

\section{References}

Braun U, Cook RTA. 2012 - Taxonomic manual of the Erysiphales (Powdery Mildews). Fungal Biodiversity Centre (CBS Biodiversity Series No. 11), Utrecht.

Glawe DA, Barlow T, Matheron ME. 2010 - First report of powdery mildew of Tecoma capensis caused by Erysiphe peruviana in North America. Plant Health Progress, 11.

Hamed MM, Mohamed MA, Ibrahim MT. 2016 - Cytotoxic activity assesment of secondary metabolites from Tecomaria capensis v. aurea. International Journal of Pharmacognosy and Phytochemical Research, 8: 1173-1182.

Hosagoudar VB, Agarwal DK. 2009 - Powdery Mildews of India: Check list. Associated Publishing Company, New Delhi.

Jothi TE, Ravichandiran V, Srinivasa BP, Suba V. 2011 - Evaluation of the analgesic action of the different extracts of Tecomaria capensis leaves. Asian Journal of Plant Science and Research, 1: 11-15.

Paul YS, Thakur VK. 2006 - Indian Erysiphaceae. Scientific Publishers, Jodhpur.

Saini NK, Singhal M, Srivastava B. 2012 - Evaluation of wound healing activity of Tecomaria capensis leaves. Chinese Journal of Natural Medicines, 10: 0138-0141.

Singh NP, Lakshminarasimhan P, Karthikeyan S, Prasanna PV. 2001 - Flora of Maharashtra State, Botanical Survey of India, Calcutta. 